\title{
O CONCEITO DE CONOTAÇÃO EM GREIMAS
}

\section{THE CONCEPT OF CONNOTATION IN GREIMAS}

\author{
Lucas Takeo SHIMODA \\ USP - Universidade de São Paulo
}

\begin{abstract}
RESUMO: O presente artigo apresenta resultados parciais de levantamento da presença do conceito de conotação nos textos de A. J. Greimas. Para organizar os dados, utilizou-se como critério as afinidades conceituais observadas em cada ocorrência do termo, bem como as possíveis conexões com outras questões correntes na semiótica da Escola de Paris. Neste artigo, serão discutidas e interpretadas as ocorrências da conotação articuladas sob três perspectivas teóricas específicas, a saber, a noção de sens commun, a veridicção e as isotopias. O primeiro discute as diferentes acepções do termo sens commun e traça as possíveis consequências dessa ambiguidade para o estudo de Greimas sobre as semióticas conotativas de Hjelmslev conforme apresentado em "Para uma sociologia do senso comum" (GREIMAS, 1975a). O segundo põe em evidência as possibilidades de trabalhar em termos de isotopias conotativas e denotativas as questões relacionadas ao jogo de fechamento e abertura de significações operado pelas relações entre a estrutura e a historicidade do texto. O terceiro trabalha com as relações entre a conotação e a veridicção, especialmente no que concerne à "atitude das culturas face aos seus signos", conforme a formulação de Yuri Lotman retomada por A. J. Greimas. Mais do que realizar um levantamento quantitativo exaustivo, o presente trabalho visa antes propor uma discussão crítica sobre o papel, ainda que marginal, do conceito de conotação na obra de Greimas.
\end{abstract}

PALAVRAS-CHAVE: Conotação; Semióticas conotativas; Senso comum; Veridicção; Isotopia.

ABSTRACT: This article presents the partial results of a search for the occurrences of the concept of connotation in Greimas' work. In order to organize the obtained data, conceptual similarities as well as the possible relations with other current issues in the semiotics of Paris School were used as criteria. In this article, the occurrences of "connotation" will be discussed and interpreted under three specific theoretical perspectives, i. e. the concept of sens commun, veridiction and isotopies. The first one discusses the different meanings of sens commun and outlines the possible consequences of this ambiguity for Greimas' study about the connotative semiotics of Hjelmslev presented in "Pour une sociologie du sens comun" (GREIMAS, 1975a). The second highlights the possibilities of working in terms of connotative and denotative isotopies issues related to the opening and closing game of the meanings operated by the relationship between the structure and the historicity of the text. The third one deals with the relationship between connotation and veridiction, especially what concerns the "culture's attitude towards its signs" according to Iuri Lotman's proposition resumed by A. J. Greimas. Rather than performing an exhaustive quantitative scanning, this work aims to propose a critical discussion about the role, even though a minor one, of the concept of connotation in Greimas' work.

KEYWORDS: Connotation; Connotative Semiotics; Common Sense; Veridiction; Isotopy.

La lecture n'est pas, quelque soit l'empire des apparences, un acte individuel. La lecture est une activité non-finie: qui osera prétendre que la lecture de 
l'oeuvre de Platon est achevée? Mais si la lecture n'a pas de fin, elle a un commencement

Claude Zilberberg (1986)

\section{Introdução}

Apesar de figurar no repertório mais básico de conceitos metalinguísticos dominados pelo assim chamado "homem comum", a conotação ocupa posição fluida na miríade conceitual das ciências da linguagem. As descrições de línguas naturais raramente se valem dessa noção ${ }^{1}$, que parece oscilar entre as disciplinas dedicadas ao estudo do sentido nas línguas naturais e aos estudos mais próximos da estética, como é o caso da estilística e da retórica. Conforme nota Göran Sonesson em seu breve texto "Denotation/Connotation" (s/d), o termo conotação é empregado para designar, em seus usos mais frequentes, quatro fenômenos de natureza distinta, a saber uma distinção lógica (análoga à oposição entre intensão e extensão da lógica e da filosofia da linguagem), uma distinção estilística (associada aos investimentos emotivos e aos fenômenos de estilo), uma implicação contextual (semelhante à noção pragmática de "inferência") e uma distinção semiótica (segundo a formulação de Hjelmslev, uma semiótica cujo plano de expressão já é também uma semiótica). A sucinta apresentação de Sonesson serve de alerta para os riscos de imprecisão que as múltiplas acepções do conceito podem oferecer. Tomando por referência a síntese de Sonesson, é preciso destacar que é a acepção propriamente hjelmsleviana da conotação que se encontra no centro das preocupações do presente trabalho.

As propostas do linguista dinamarquês acerca da conotação ${ }^{2}$ parecem ter sido pouco aproveitadas, conforme já notado pelo próprio Greimas: "[...] temos de reconhecer como bem pouco desenvolvida a teoria hjelmsleviana relativa aos sistemas de conotação. O pouco que já se disse a respeito, ou bem não é levado a sério, ou bem se vê passível de várias interpretações" (GREIMAS, 1975a, p. 89). De maneira geral, pode-se constatar que esse conceito desempenha um papel mínimo nos trabalhos da semiótica greimasiana. Nos raros casos em que acontece, a retomada desse conceito é feita via Roland Barthes (cf. LOPES, 1997; CAÑIZAL, 1990, a título de exemplo).

A apropriação particular da conotação enquanto lugar de encontro da retórica e da ideologia (cf. BARTHES, 2004, p. 97-98) tornou o conceito fortemente marcado pelo projeto intelectual semioclasta e desmitificante de Barthes (FAGES, 1979, p. 120-122), o que pode ter causado seu banimento para a periferia da semiótica greimasiana. Esse efeito de exclusão pode ter sido reforçado por leituras reducionistas que ora limitam o projeto teórico de Greimas a um estudo narratológico - conforme notado por Beividas e Lopes (2012, p. 33-34) -, ora se apropriam de suas ferramentas analíticas mais populares de maneira excessivamente instrumentalizada.

Em contraposição à boa fortuna do programa narrativo e do quadrado semiótico, a conotação ocupa espaço marginal, porém não desprezível, nas reflexões de A. J. Greimas. Considerando que Greimas e Barthes travaram conhecimento da obra de Hjelmslev juntos na estadia em Alexandria (HÉNAULT, 2006, p. 128-129), seria interessante observar de que maneira a conotação é entendida por um e outro autor. Já é largamente conhecido o papel

1Por exemplo, para Leonard Bloomfield, os fenômenos conotativos representam um obstáculo que obstrui o trabalho de descrição no campo do sentido (BLOOMFIELD, 1970).

2 Por fidelidade à letra de L. Hjelmslev, seria mais adequado falar de "semióticas conotativas". No entanto, tais oscilações terminológicas serão colocadas em suspenso tendo em vista a variação observada no próprio material em análise. 
fundamental dessa formulação teórica no pensamento de Barthes (cf. DOSSE, 1993, p. 98100). Em contrapartida, pouco ou quase nada se diz sobre sua presença nos textos de Greimas.

\section{Método de trabalho}

Antes de passar para a discussão propriamente teórica, cumpre fazer algumas observações no que diz respeito aos procedimentos metodológicos. Os dados em discussão foram obtidos mediante breve levantamento do metatermo "conotação" e suas derivações. O escopo do material analisado abrange os seguintes títulos: Semântica estrutural (1966), Sobre o sentido (1975a[1970]), Ensaios de semiótica poética (1975b), Semiótica narrativa e textual (1977), Semiótica e ciências sociais (1981), Dicionário de Semiótica (2012[1979]), “A enunciação: uma postura epistemológica" (1974), Análise do discurso em ciências sociais (1986 [1979]), Du Sens II (1983), Sémiotique: dictionnaire raisonné de la theorie du langage vol. II (1986), "Conversation" (1986), Da imperfeição (2002 [1987]) e Semiótica das paixões (1993).

Além das ocorrências no texto greimasiano, é preciso registrar também a presença da conotação em textos redigidos por outros autores e publicados em obras organizadas por Greimas. Em Ensaios de Semiótica Poética (1975b), encontram-se duas ocorrências da conotação dignas de nota. Na primeira delas, Michel Arrivé convoca a conotação e a metassemiótica para discutir a estrutura sígnica e a plurivocidade de um texto de Jarry (ARRIVÉ, 1975, p. 79-95). Em capítulo intitulado "Semanálise e produção de sentido" dessa mesma obra, Julia Kristeva menciona, apenas de passagem e com reservas, o poder atribuído por Hjelmslev aos conotadores de dar conta da produtividade virtualmente infinita dos textos (KRISTEVA, 1975, p. 244). Não há evidências de que Greimas teria endossado tais aplicações, motivo pelo qual elas serão mantidas em segundo plano. Porém, a simples presença dessa noção nessa destacada obra da semiótica serve de testemunho de sua disseminação naqueles anos. Tratando ainda das ocorrências da conotação em publicações organizadas por Greimas, gostaríamos de chamar atenção para a explanação dada por Per Aage Brandt no verbete "connotation" do Dicionnaire II (1986). Não se pode assumir que a postura desses autores reflete sem desvios a visão de Greimas sobre o assunto. A atmosfera de dubiedade que cerca o segundo tomo do Dicionário de Semiótica reforça no leitor a sensação de desconfiança diante das poucas linhas dedicadas à conotação e categorizadas sob a rubrica "D", convencionalizada pelos organizadores para indicar "debate", "divergência", "discussão" ou mesmo "digressão".

Os textos em que o termo ocorre foram submetidos a uma leitura mais aprofundada com o objetivo de delinear melhor em que contexto a conotação é convocada. Nessa fase do estudo, buscou-se compreender com mais nitidez as nuances conceituais, os pressupostos teóricos e as decorrências analíticas implicadas em cada caso. A partir disso, foi possível traçar relações com outros elementos da arquitetura teórica da semiótica e, ocasionalmente, com referências de outras disciplinas. Com isso, foi possível organizar as ocorrências de conotação conforme suas afinidades conceituais. Os dados discutidos no presente trabalho abrangem três campos de investigação, a saber: o sens commun, a veridicção e as isotopias de leitura. Restam ainda a ser publicados os resultados pertinentes às problemáticas da conotação enquanto fenômeno de estilo e da hierarquia dos níveis de análise. Cabe ressaltar que, a despeito de todos os esforços em garantir a confiabilidade da coleta e da análise dos dados, o alcance de um estudo dessa natureza está sempre condicionado a limitações de ordem material. 


\section{Conotação e o "sens commun"}

Tendo em mente que Sobre o sentido reúne diversos estudos publicados por Greimas ao longo da década de sessenta, seria conveniente detalhar que a conotação aparece em dois momentos específicos. A primeira convocação do conceito ocorre em seu estudo sobre a gestualidade apresentado no capítulo "Para uma semiótica do mundo natural" (1975a, p. 4685), publicado originalmente em 1968, enquanto a segunda convocação aparece no capítulo seguinte intitulado "Por uma sociologia do bom-senso" (1975a, p. 86-96), publicado no mesmo ano e inteiramente dedicado ao conceito de conotação segundo a proposta de Hjelmslev ${ }^{3}$. As reflexões presentes nessa obra suscitam questões que merecem ser revisitadas. Observe-se a seguinte citação, em que Greimas discute o papel da semiótica do mundo natural para entender a significação da gestualidade:

A partir disto pode-se esboçar um ensaio de tipologia das culturas baseado numa tipologia das relações estruturais que definem os signos naturais (J. Lotman). Podem-se tirar duas conclusões destas reflexões preliminares; em primeiro lugar, a hipótese pela qual o mundo natural se deixa tratar como um objeto semiótico: os signos naturais, devido à existência de uma relação semiótica, e quaisquer que sejam as suas articulações, têm estatuto de signos. Esta abordagem, por outro lado, nada nos ensina sobre a natureza e organização interna dos signos: dependendo de uma interpretação da relação semiótica, que é uma variável, é uma reflexão metassemiótica sobre os signos, uma conotação semiótica, que transforma de diferentes maneiras os signos naturais em signos culturais. (GREIMAS, 1975a, p. 51, grifo nosso).

É interessante notar que Greimas tenha recorrido à conotação para tentar abordar a problemática da transformação dos signos naturais em signos culturais. Mesmo em uma leitura mais descompromissada, nota-se já nesse trecho que a concepção de conotação destoa bastante da ideia vulgarizada de sentido sugerido por uma palavra ou atribuído por associação. Mais do que um mero "acréscimo de sentido", a conotação vem desempenhar um papel-chave na economia teórica da semiótica em construção naquele momento histórico.

A proposição de Greimas explora de maneira original a formulação teórica das semióticas conotativas, apresentada por Louis Hjelmslev, segundo a qual a semiótica conotativa é uma semiótica cujo plano de expressão já é, em si, uma semiótica (HJELMSLEV, 2006, p. 125). Essa conceitualização reverbera nas reflexões traçadas por Greimas nesse estudo acerca da emergência da significação nos signos naturais. No estudo em questão, o semioticista lituano argumenta que a concepção de mundo natural enquanto instância ontológica extralinguística contradiz os fundamentos epistemológicos da semiótica e propõe tratar os assim chamados objetos do mundo como signos naturais dotados de um conteúdo e uma expressão. Assim, o mundo natural como um todo já constituiria em si uma semiótica primeira e poderia ser considerada então como uma semiótica denotativa. Assumindo essa proposição, toda operação de culturalização desses dados naturais já resultaria em uma semiótica conotativa.

Essa leitura da conotação pode parecer estranha tanto ao leigo, familiarizado apenas com as definições apresentadas por manuais de divulgação, quanto ao estudioso habituado a

3 Além desses casos, há também uma brevíssima menção no último parágrafo do capítulo "A linguística estrutural e a poética" (1975a, p. 265). Embora não se possa desprezar o uso peculiar da expressão "conotação eufórica e disfórica" para se referir às valorações do texto poético, deixaremos por ora esse caso em segundo plano, pois ocupa uma posição periférica na análise em questão.

Disponível em: http://seer.fclar.unesp.br/casa 
enxergar no projeto teórico de Greimas apenas suas ferramentas analíticas tornadas mais populares. A peculiar interpretação de Greimas da semiótica conotativa enquanto transformação do signo natural em signo cultural não pode ser considerada como mero palpite intelectual sem consequências. Essa ideia reaparece posteriormente no capítulo "Para uma sociologia do bom-senso" e constitui, segundo o autor, um dos grandes campos de significação englobados pela conotação. A esse respeito, o autor afirma que os sistemas conotativos se comportam como sistemas deformantes e incidem sobre o modo do parecer dos objetos semióticos, ao passo que a sua estrutura interna, pertencente ao modo do ser, se torna reificada. Assim, a dimensão conotativa estabelece um campo em que objetos culturais tornados opacos circulam e constroem uma práxis cultural (GREIMAS, 1975a, p. 92-95).

Se nos limitássemos a aceitar a conotação como instância mediadora da transposição do signo natural para o signo cultural, o conceito já desempenharia um papel não desprezível na arquitetura teórica da semiótica. No entanto, gostaríamos ainda de trazer à tona outras evidências que podem não apenas corroborar essa interpretação, mas também trazer outros desdobramentos não desprezíveis. Ao traduzir o título original "Pour une sociologie du sens commun" como "Para uma sociologia do bom-senso", a edição brasileira pode ter ofuscado a força das propostas de Greimas sobre o que pode ser entendido pela expressão "sens commun", definida pelo dicionário Petit Robert como "manière de juger, d'agir commune à tous les hommes".

Por sua vez, a expressão do português brasileiro "bom senso" diverge consideravelmente dessa ideia, pendendo mais para uma faculdade moral. Segundo o Dicionário Houaiss, o "bom senso" é definido como "capacidade ou poder de distinguir o verdadeiro do falso, o bom do mau, o bem do mal; julgamento correto e equilibrado". A definição do Dicionário Caldas Aulete aponta para a mesma direção: "I Filos.: Em questões correntes e habituais, aptidão intuitiva de discernir entre o verdadeiro e o falso, o certo e o errado, o bom e o mau etc. 2. Uso adequado do raciocínio e da razão na avaliação de situações e tomada de decisões". Além disso, cumpre ressaltar também a interessante polissemia do termo "sens" em francês, que se refere igualmente ao aspecto inteligível da significação (Dicionário Le Petit Robert: "Idée ou ensemble d'idées intelligible que représente un signe ou un ensemble de signes") e à sensibilidade aos estímulos físicos (Dicionário Le Petit Robert: "Faculté d'éprouver les impressions que font les objets matériels"). Desse modo, a expressão "sens commun" poderia remeter ambiguamente tanto a um "sentido comum" quanto a uma "sensorialidade comum". Os raciocínios traçados de maneira intuitiva até esse ponto fornecem evidências de que a tradução brasileira pode ter eclipsado ideias fecundas presentes no texto greimasiano.

Seria uma atitude imprudente pretender justificar a tal proposição lançando mão unicamente de definições de dicionários não-especializados. Dando um passo à frente, os contornos dessa hipótese tornam-se mais nítidos. Conforme apresentada pelo Dicionário Houaiss sob a rubrica "filosofia", a expressão "senso comum" é definida da seguinte maneira: "no aristotelismo, na escolástica e no cartesianismo, faculdade cognitiva cuja função é reunir as múltiplas impressões dos nossos sentidos, com o objetivo de unificar a imagem de um objeto percebido". Uma breve consulta a dicionários de filosofia ratifica, ao menos parcialmente, essa duplicidade de leituras do sens commun, que aponta ora para o vetor sensível (sensorialidade), ora para o vetor inteligível (sentido).

\subsection{Acepção estésica}

A dupla leitura, deduzida até aqui algo ingenuamente, pode ser corroborada pelo 
estudo "Common Sens and Basic Beliefs: from Certainity to Happiness" de Herman Parret, semioticista de sólida formação filosófica . A seguinte citação extraída de um dos primeiros parágrafos do texto de $\mathrm{H}$. Parret assinala a dupla leitura que o conceito de sens commun assumiu ao longo da história e, logo em seguida, atribui a acepção estésica (a saber, aquela que relaciona o sens commun à sensorialidade) à tradição aristotélica.

Há duas grandes linhas de interesse no senso comum na história das doutrinas filosóficas. A linha aristotélica introduz o senso comum como uma categoria na teoria da percepção: o senso comum é usado para explicar a consciência da sensação. É evidente que essa linha continua pelo menos até George Edward Moore, que ainda define senso comum em termos de percepção, sensação e certeza de conhecimento. (PARRET, 1983, p. 217, tradução nossa).

A explanação não deixa dúvida quanto aos laços de parentesco entre o conceito aqui discutido e as questões da percepção e da sensorialidade. Uma breve consulta a dicionários de filosofia podem confirmar essa possibilidade de leitura. O verbete "senso comum" do Dicionário de filosofia de Nicola Abbagnano registra a expressão original em grego (koiné aisthésis) e explica o entendimento aristotélico desse conceito enquanto "capacidade geral de sentir", que tem por função tanto "constituir a consciência da sensação" quanto "perceber as determinações sensíveis comuns, como o movimento, o repouso, o aspecto, o tamanho, o número e a unidade" (cf. ABBAGNANO, 2000, p. 872). Vale a pena chamar a atenção para a distinção aristotélica entre sensíveis próprios e sensíveis comuns. A entrada "Perception (aisthésis)" do Dictionnaire Aristote explica que os primeiros seriam as qualidades sensoriais apreendidas por um canal sensorial específico, ao passo que os segundos seriam percebidos por todos os sentidos (PELLEGRIN, 2007, p. 156, tradução nossa). Logo na sequência, esse autor esclarece que os sensíveis comuns são fortemente vinculados aos sensíveis próprios, mas não se limitam a eles: "Os sensíveis comuns são percebidos - de outro modo, eles não seriam chamados 'sensíveis' - mas eles não o são por um órgão sensorial particular e só são percebidos em associação com um ou mais sensíveis próprios: [...]” (PELLEGRIN, idem, ibidem). Tomando em consideração essa função unificadora dos sensíveis comuns, ganha relevo o conceito clássico de sinestesia, conforme se vê explicado em nota de rodapé do verbete "senso comum" do Vocabulário técnico e crítico da filosofia de André Lalande:

Para Aristóteles, a koiné aisthésis, que também designa por [sic!] proton aisthetikon, kírion aisthetirion (BONITZ, Ind. Arist., 20b16), exerce várias funções: este 'senso comum' reporta-se tanto à unidade do sujeito sensitivo como à do objeto sentido; percebe, além disso, os 'sensíveis comuns' e, por fim, nos dá a consciência da sensação, aquilo a que os comentadores gregos chamam a synaisthesis. Basta a cada sentido sentir o seu sensível próprio, e não é pela vista que vemos que somos capazes de ver (De somno, II, 455a15) [...]. (LALANDE, 1999, p. 996-997, nota de rodapé).

O corpo de texto do verbete explica que esse conceito conservou na tradição escolástica a definição de "sentido central que teria por função coordenar as sensações próprias de cada sentido especial" (LALANDE, 1999, p. 997). Segundo o Dicionário Oxford de Filosofia, esse entendimento perdurou pelo menos até o pensamento de Descartes (cf. BLACKBURN, 1997, p. 355). Embora não com a mesma proeminência, as ideias de Aristóteles parecem ter deixado resquícios no conceito de sens commun, a se pautar pela sua 
retomada no século XX por Hannah Arendt. Em A condição do homem moderno, a autora convoca claramente a concepção aristotélica ao fazer referência à problemática da percepção e da sensorialidade: "É em virtude do senso comum que vê-se que as percepções sensoriais desvelam o real e que elas não são sentidas simplesmente como irritações dos nervos ou sensações de resistência do corpo" (ARENDT, 1983, p. 234, apud LORIES, 1998, p. 3, tradução nossa).

\title{
2.2 Acepção epistêmica
}

A segunda linha de interesse referida por H. Parret aponta para o entendimento de sens commun mais voltado ao seu aspecto inteligível. Na sequência da citação já apresentada anteriormente, esse semioticista se refere a essa linha "menos notável" de desenvolvimento do conceito, que ele aprofundará nas páginas seguintes de seu trabalho:

\begin{abstract}
Além dessa linha que vai de Aristóteles ao empirismo escocês e inglês, há outra, menos notável, que começa com a filosofia estoica da ciência e a geometria euclidiana. Aqui, o conceito de senso comum está apoiado na noção de koinai ennoiai desenvolvida pelos estoicos e usada para os axiomas das teorias (bem como a geometria e a matemática pura); e leva até à Gemeinsinn de Kant, muito distante da percepção e da sensação, tão distante delas quanto o são também as leis morais e o Imperativo Categórico. (PARRET, 1983, p. 217, tradução nossa).
\end{abstract}

É interessante frisar a ressalva de Parret de que, embora a ideia tenha ganhado ampla importância no pensamento de Kant sobre o juízo do gosto, ela diverge consideravelmente de suas fontes ${ }^{4}$. Sob esse ponto de vista, o sens commun agiria como um mecanismo coletivo regulatório de assunções epistêmicas irrefutáveis, conforme se vê na definição do Dicionário de filosofia de Mário Bunge: "Faculdade ou juízo situados entre a especulação desbragada, de um lado, e, de outro, uma asserção bem fundada e uma suposição culta" (BUNGE, 2002, p. 350). Um leitor familiarizado com as reflexões semióticas sobre a tensividade (cf. ZILBERBERG, 2006, 2011) dificilmente deixará de notar que o sens commun ocupa a posição intermediária entre o excesso e a falta nos mundos da razão. A definição dada pelo Dicionário Oxford ressalta o papel atenuador dos excessos intelectuais praticado pelo ceticismo e pela elucubração filosófica:

[...] juízos inflexíveis que não cedem ao ceticismo e que não se encontram demasiado contaminados pelas teorias. Nesse sentido, admite-se que o senso comum faz parte das pessoas antes de estas se tornarem demasiado filosóficas. [...] O termo tornou-se proeminente na filosofia após Moore ter sustentado, em 'A defense of Common Sense', que nenhum argumento filosófico que vise estabelecer o ceticismo poderia ser mais certo que suas convicções de senso comum. (BLACKBURN, 1997, p. 355).

Por sua vez, a explanação apresentada pelo Dictionnaire de philosophie de JeanPierre Zarader ressalta o papel de reparador da falta de discernimento no caso das ditas "enfermidades intelectuais" como os "fanatismos" e os "delírios entusiastas":

4 Sobre a concepção kantiana de senso comum, cf. CAYGILL, 2000, p. 218-219, 248, 286-287.

Disponível em: http://seer.fclar.unesp.br/casa 
O homem de senso comum é a figura do não-filósofo. Ele representa a norma de um espírito saudável cujo julgamento correto, justo e adequado constitui o bom senso. Tal norma pode designar: 1) a razão que se exerce habitualmente e normalmente na vida comum, 2) em um sentido normativo, a 'saúde' do juízo ou o espírito humano que pode se curar dos prejulgamentos e das enfermidades intelectuais (fanatismo, melancolia, delírios entusiastas) graças a uma empreitada filosófica 'terapêutica' (ZARADER, 2007, verbete "sens commun/bon sens", tradução nossa).

\subsection{0 comum dos sensos}

Antes de retornar ao texto greimasiano, gostaríamos de realçar nesse ponto o mecanismo de regulação coletiva do caráter "comunal" - tomando a liberdade da criação neológica - dos "sensos comuns", sejam eles tomados em seus aspectos inteligíveis ou sensíveis. No caso dos primeiros, a função de controle dos obscurantismos intelectuais é nitidamente destacada na terceira entrada do verbete "senso comum" do Dicionário de André Lalande: "Na linguagem filosófica contemporânea, o senso comum é o conjunto das opiniões tão geralmente admitidas, numa dada época e num dado meio, que as opiniões contrárias aparecem como aberrações individuais" (LALANDE, 1999, p. 996-998). A oposição entre o foro individual e o coletivo aparece como o fator responsável por deslegitimar as idiossincrasias no universo das ideias. A seguinte afirmação de H. Parret deixa bem claro que o sens commun coíbe as extrapolações mentais nutridas na introspecção profunda do indivíduo em favor de sua comunicabilidade: "De fato, o senso comum enquanto conceito tem sido usado como arma poderosa com força conclusiva contra o ceticismo, de um lado, e contra o solipsismo radical, de outro lado" (PARRET, 1983, p. 219, tradução nossa) ${ }^{5}$.

No âmbito da sensorialidade, as reflexões de H. Arendt deixam bem claro que o mundo do sens commun enquanto percepções sensoriais só pode ser considerado legítimo em função de sua comunicabilidade: "Em uma dada coletividade, uma diminuição notável do senso comum [...]. é então um sinal quase infalível de alienação ao mundo" (ARENDT, 1983, p. 235, apud LORIES, 1998, p. 3, tradução nossa). Em outro momento, vê-se reafirmada a necessidade de poder partilhar com o outro o "mundo real" construído pelos sentidos:

Esse senso comum $[\ldots]$ nos revela a natureza do mundo enquanto um mundo comum. [...] Graças a ele, nossos cinco sentidos estritamente particulares e 'subjetivos', com outros dados sensoriais, podem se ajustar a um mundo nãosubjetivo e 'objetivo' que temos em comum e partilhamos com o outro. (ARENDT, 1972, p. 282-283. In: LORIES, 1998, p. 2, tradução nossa).

Ao discorrer sobre a recepção do sens commun pelo pensamento de $\mathrm{H}$. Arendt, a pesquisadora Danielle Lories reitera que “ [...] esse senso comum, não contente em assegurar a partilha de um mesmo mundo pelos diferentes sentidos, é também comunitário: a realidade da coisa do mundo está em nossa atitude em partilhá-la com o outro” (LORIES, 1998, p. 2,

5 Deve-se ainda destacar a advertência, expressa pelo próprio H. Parret, de que é preciso distinguir essas assunções epistêmicas irrefutáveis daquelas premissas normalmente convocadas a título de estratégia retórica, ora para fortalecer argumentos carentes de fundamentação lógica, ora para inibir a originalidade do interlocutário ou mesmo para impor preconceitos ideológicos. Ainda segundo esse autor, o senso comum com valor ideológico é ancorado sócio-historicamente, ao passo que as proposições de senso comum com valor epistêmico não podem ser relativizadas (cf. PARRET, 1983, p. 218-219). 
tradução nossa) ${ }^{6}$ Vê-se, assim, que tanto no caso das assunções epistêmicas quanto no caso da sensorialidade, o que permanece em comum nas duas leituras do conceito em questão é a propriedade de partilha. Para finalizar esse breve excurso, cumpre ressaltar a necessidade de aprofundar em trabalhos posteriores a revisão do conceito de sens commun. No que tange às questões de interesse do presente trabalho, cremos ter levantado evidências suficientes que podem trazer novas luzes para a leitura do texto greimasiano.

\subsection{Voltando a Greimas}

Se se assumem - ao menos provisoriamente - essas possíveis leituras de sens commun, o estudo de Greimas ganha proporções audaciosas na medida em que busca trabalhar um problema discutido no campo da filosofia com as ferramentas teóricas da semiótica. Nesse sentido, parece especialmente sugestivo que o semioticista lituano tenha dado o título "Pour une sociologie du sens commun" a um texto que trata das semióticas conotativas de L. Hjelmslev. Na subseção dedicada ao ser e ao parecer dos objetos semióticos, Greimas antevê os futuros movimentos da semiótica em direção à estesia e ao vivido e traça uma associação entre esse campo de estudos e a conotação. A se pautar pelas declarações de Greimas, esse nível de investigação representa tarefa inescapável dos desenvolvimentos da pesquisa semiótica.

O reconhecimento do fenômeno da conotação tem uma dupla importância metodológica: [...]; além do mais, permite integrar na pesquisa semiótica, e se fazer beneficiar da metodologia desta última, um campo de significações cuja apreensão científica parece impossível ainda, e que frequentemente invocamos como o nível do vivido e do sentido, do cotidiano e do humano, para contrapô-lo ao caráter abstrato e desencarnado da semiótica. (GREIMAS, 1975a, p. 93).

À primeira vista, causa certo estranhamento ver convocada a ideia de conotação para tratar esse tipo de problemática. No entanto, o próprio Greimas parece estar convicto da necessidade dessa "extrapolação" e recusa as leituras excessivamente simplificadoras das ideias do linguista dinamarquês:

As extrapolações que acabamos de fazer - e que nos propomos a continuar fazendo - podem parecer sem medida comum com a lista apenas alusiva de Hjelmslev. E o parecerão ainda mais aos adeptos do pensamento do mestre dinamarquês. Na verdade, é difícil admitir que as páginas consagradas, no quadro dos Prolegômenos, às linguagens de conotação sejam apenas a reintrodução de uma pseudo-estilística ultrapassada do que o estabelecimento de uma nova dimensão semiótica na economia geral da teoria da linguagem (GREIMAS, 1975a, p. 92).

Essa concepção de conotação pode parecer inusitada por não coincidir exatamente com a pequena lista alusiva de estilos e fisionomias apresentada por Hjelmslev no capítulo de seus Prolegômenos dedicado às semióticas conotativas (2006, p. 122). A heterogeneidade de acepções que circulam nesse texto de Greimas foi devidamente notada em artigo de Denis Bertrand (2009), em que este semioticista propõe uma divisão da exposição de Greimas em

6 Não é demasiado destacar a observação de que o senso comum no pensamento de H. Arendt funde as concepções aristotélica e kantiana (LORIES, 1998, p. 3). 
duas partes nitidamente distintas. Na primeira parte, Greimas ocupa-se da conotação (tratada aos moldes da estrutura da linguagem, e não apenas como epifenômenos pontuais nos signos) e discute com grande rigor a construção de uma tipologia das chamadas "zonas de conotação". Reconhece-se claramente a forte orientação ao "inventário aproximativo e alusivo" de Hjelmslev, bem como referências à sociolinguística e a uma "estilística social". $\mathrm{Na}$ segunda parte, o tom do texto altera-se consideravelmente. A discussão acerca da taxionomia de estilos dá lugar a ponderações sobre o ser e o parecer dos objetos semióticos, bem como sobre o vivido e o sentido do cotidiano humano. As referências a Hjelmslev e à sociolinguística, dominantes no primeiro momento do texto, dão lugar a alusões a Sigmund Freud e Marcel Griaule. No mesmo artigo, Bertrand (2009) observa com precisão as incompatibilidades geradas por essas diferentes leituras e a dificuldade de levar a cabo ambas proposições sem sobrecarregar excessivamente o conceito de conotação. Assim, este semioticista traz à luz os fatores que contribuíram para o paradoxal abandono da conotação, pois foi esse conceito que permitiu antever a inclusão do sensível nas reflexões semióticas muitos anos antes da publicação de Da imperfeição.

É difícil não se surpreender com o alcance das reflexões de Greimas, que, apenas dois anos depois da publicação de sua Semântica estrutural (1966), já refletia sobre questões que viriam levar ao menos vinte anos para ocupar o centro das preocupações dos semioticistas. Mais do que apenas um exercício de elucubração científica, essa leitura da conotação parece ter habitado o pensamento de Greimas ao menos até a publicação do primeiro tomo do Dicionário de Semiótica. Após apresentar sucintamente as possibilidades de entrever uma motivação intrínseca entre signos, Greimas finaliza o texto do verbete "Motivação" atribuindo às conotações sociais o papel regulador da atitude das culturas perante os signos que nela circulam ${ }^{7}$.

A motivação, distinta da analogia (tratada em 1), deve ser incorporada à problemática das conotações sociais: segundo as culturas, é possível reconhecer ora a tendência a 'naturalizar' o arbitrário, motivando-o; ora a 'culturalizar' o motivado, intelectualizando-o (R. Barthes). (GREIMAS; COURTÉS, 2012, p. 322).

Conforme se nota na citação acima, a leitura greimasiana da conotação está intimamente ligada ao trânsito incessante entre o natural e o cultural. Por um lado, a semiótica conotativa age como princípio estrutural de organização taxionômica das culturas e fornece o modelo para uma "sociologia de sensos comuns". A ideia de senso comum, considerada como fronteira de delimitação entre universos culturais e concebida como uma semiótica conotativa, aparece nitidamente nas linhas que encerram esse capítulo de $D u$ sens:

Caso se possa conceber a cultura como uma semiótica, sua existência vai postular uma semiótica conotativa paralela cujas múltiplas manifestações envolvem o homem de todos os lados, fechando-o num ambiente de realidade tranquilizadora (GREIMAS, 1975a, p. 96).

Por outro lado, as questões do sensível e da percepção não deixam de cumprir o seu papel na construção desse "ambiente de realidade tranquilizadora", conforme nota Denis Bertrand em seu estudo sobre as metáforas da "cortina de fumaça" (écran de fumée) e da "mordida sobre o real" (morsure sur le réel) em Du sens: "Desse modo, esclarecem-se as duas

7 Cf. Tópico "Conotação e veridicção". 
metáforas de Du sens, 'cortina de fumaça' e 'mordida sobre o real', coextensivas uma à outra e articulando as dimensões formais da relação, cultural da práxis discursiva e sensível da percepção do mundo natural.” (BERTRAND, 2006, p. 19, tradução nossa).

A convocação das qualidades sensíveis na construção dessa "rede de significações alienantes, dentro da qual ele [o homem] acredita viver, sentir, julgar e crer" (GREIMAS, 1975a, p. 93) reativa a acepção estésica do sens commun, presente no título desse intrigante estudo de Greimas, conforme proposto aqui. Algumas evidências textuais podem ser convocadas a fim de corroborar essa proposta de leitura. Em diversos momentos, Greimas emprega a expressão sens commun para designar o assim chamado mundo natural e seus dados sensoriais. No capítulo "A estrutura semântica" de Du sens, o líder da Escola de Paris discute a necessidade de distinguir forma científica e forma semiótica e assim declara:

[...]; se, por exemplo, a química enquanto ciência é uma organização formal específica a um domínio dado de substância, logo os elementos químicos são as unidades mínimas ( $=$ os traços distintivos) cuja combinatória produz, no plano da manifestação, um dos aspectos do que se chama, por falta de um termo mais apropriado, o mundo do senso comum. (GREIMAS, 1975a, p. 39, grifo nosso).

Algumas páginas adiante, a correlação entre mundo natural e mundo do senso comum torna a ocorrer. Ao que tudo indica, essas proposições corroboram a proposta de Greimas de tratar as culturas como uma sociologia de sensos comuns, na medida em que elas atribuem, cada uma a seu modo, formas semióticas distintas aos dados fornecidos pela forma científica.

Se considerarmos que o chamado mundo do senso comum é apenas o nível onde se manifesta a forma científica (o universo como ciência), vemos que este mundo manifestado, sendo a substância da forma científica, ao mesmo tempo é substância da forma semiótica, que articula em categorias perceptivas qualidades visuais, olfativas ou gustativas. (GREIMAS, 1975a, p. 42, grifo nosso).

Em Semântica estrutural, pode-se já testemunhar a presença dessas ideias. Após a célebre e seminal declaração sobre o estatuto da percepção em seu projeto semiótico ainda a se desenvolver - "É com conhecimento de causa que nos propomos a considerar a percepção como o lugar não linguístico onde se situa a apreensão da significação" (GREIMAS, 1976a, p. 15.) - Greimas alude novamente ao senso comum para tratar das apreensões perceptivas dos dados sensoriais: "No entanto, a afirmação de que as significações do mundo humano se situam no nível da percepção consistem em definir a exploração no mundo do senso comum, ou, como se diz, no mundo sensível" (GREIMAS, 1976a, p. 16, grifo nosso).

A proximidade cronológica e o período dessas publicações poderiam dar a entender que tratam-se aqui apenas de formulações conceituais ainda em estágio de amadurecimento. No entanto, essa impressão se dissipa com uma rápida consulta ao Dicionário de Semiótica, obra tida como a grande súmula conceitual da disciplina. No verbete "Mundo natural", encontra-se novamente o senso comum associado ao universo da sensorialidade e do vivido: "Entendemos por mundo natural o parecer segundo o qual o universo se apresenta ao homem como um conjunto de qualidades sensíveis, dotado de certa organização que faz com que o designemos por vezes como 'mundo do senso comum"' (GREIMAS; COURTÉS, 2012, p. 324). Em discussão sobre o delicado estatuto das semióticas chamadas naturais, o seguinte 
trecho do verbete "Semiótica" ratifica essa correlação: "Elas [semióticas naturais] são chamadas 'naturais' porque são anteriores ao homem - ele mergulha na sua língua materna, é projetado, desde seu nascimento no mundo do senso comum - que a elas submete, mas não as constrói” (GREIMAS; COURTÉS, 2012, p. 449).

Mesmo após o grande marco do projeto teórico da Escola de Paris, essa associação entre sens commun e mundo significante torna a aparecer na letra do semioticista lituano, ainda que de maneira pontual. Na introdução de Semiótica das Paixões, pode-se ler a seguinte afirmação: "Não é mais o mundo natural que vem em direção ao sujeito, mas o sujeito que se proclama mestre do mundo. O mundo dito natural, o do sentido comum, torna-se então o mundo para o homem, mundo que se poderia dizer humano"8 (GREIMAS; FONTANILLE, 1993, p. 19).

Levando tudo isso em consideração, as evidências sugerem que, no pensamento de Greimas, a ideia de sens commun sempre esteve relacionada às questões da sensibilidade. A recorrência de menções desse conceito para fazer referência ao mundo natural, do vivido e do sensível mostra que não se trata apenas de um modismo teórico; ao contrário, ela permeia diversos pontos da obra do semioticista lituano, desde o gesto inaugural da obra fundadora até a guinada rumo ao sensível em seu último livro, passando pelo ponto de maturidade da disciplina demarcado pelo primeiro volume do Dicionário de Semiótica (GREIMAS; COURTÉS, 2012). Com esse cenário em vista, há bons motivos para acreditar que a proposta de Greimas de aplicar as semióticas conotativas de L. Hjelmslev para construir uma sociologia do senso comum tinha consequências ambiciosas, relegadas ao esquecimento pelos desenvolvimentos posteriores da disciplina, que privilegiaram as questões das modalidades, do percurso narrativo, da figuratividade entre outros tópicos. Um estudo de maior fôlego seria necessário para aprofundar tanto a questão filosófica relacionada às diversas facetas do conceito de sens commun, quanto a das influências do pensamento de A. J. Greimas por L. Hjelmslev. Por ora, é suficiente propor, conforme nos mostram as evidências textuais discutidas até aqui, que as reflexões do semioticista lituano acerca das semióticas conotativas não se tratavam de mera aposta teórica.

\section{Conotação e isotopias de leitura}

Retomemos o capítulo "Para uma sociologia do bom-senso" de Greimas. Logo no início de seu texto, o autor nota que a importância atribuída aos conceitos de denotação e conotação no pensamento de Hjelmslev depende de como se lê seus Prolegômenos (1975a, p. 86-87). Com essa observação, Greimas nota argutamente o papel enigmático do penúltimo capítulo dessa obra singular, o qual reposiciona a reflexão desenvolvida até aquele ponto e procura expandir seu poder heurístico (HJELMSLEV, 2006, p. 121). O autor toma em consideração a cautelosa postura de Hjelmslev e declara em seguida que, embora seja forçoso considerar os diversos sistemas semióticos implicados por um texto dado, ainda permanece pouco clara a maneira mais adequada de abordá-los. Logo em seguida, encontra-se uma valiosa advertência a respeito do modo de proceder diante desses casos:

Isto é de tal forma verdadeiro, que a luta contra o caráter logomáquico dos textos, a pesquisa de condições objetivas para o estabelecimento de uma isotopia que permita a leitura é uma das principais preocupações da descrição semântica em sua fase inicial. Colocado frente a um texto qualquer, o analista se vê diante de uma escolha: deverá ou bem procurar

8 Note-se que, dessa vez, a tradução brasileira opta pela expressão "sentido comum" para "sens commun". Disponível em: http://seer.fclar.unesp.br/casa 
construir um modelo que dará conta de uma isotopia denotativa do texto, e proceder, para tanto, à eliminação de tudo o que, no texto, pertença a outros sistemas semióticos; ou bem considerar - a título de hipótese, ou porque isso já corresponde ao estado de avanço dos conhecimentos linguísticos - como já conhecida a estrutura denotativa, e se ocupar do recenseamento dos elementos que, embora contidos no texto, pertencem a outros sistemas que não o sistema denotativo; procurará então construir modelos interpretativos desses diversos elementos. Observaremos, para voltar a Hjelmslev, que tais elementos estrangeiros são, para ele, conotadores e que os sistemas possíveis de serem postulados e descritos a partir de isotopias conotativas são linguagens de conotação. (GREIMAS, 1975a, p. 87, grifo do autor).

Pode-se notar que Greimas coloca no campo da denotação os esforços teóricos para deslindar as isotopias que permitem controlar as leituras virtualmente infinitas propiciadas pelo "caráter logomáquico dos textos". Além disso, o semioticista chama a atenção para a necessidade, já apontada por Hjelmslev (2006, p. 125) e reiterada pelo próprio Greimas em momento posterior (GREIMAS; COURTÉS, 2012, p. 92), de conhecer a estrutura da semiótica denotativa antes de iniciar a análise da semiótica conotativa. Esse ponto parece especialmente ilustrativo das divergências de leitura entre Greimas e Barthes sobre as propostas hjelmslevianas para as semióticas conotativas.

A oposição estabelecida pelo autor entre isotopias denotativas e isotopias conotativas merece ser examinada mais detidamente. A se pautar pelo trecho extraído de $D u$ sens, a mencionada "isotopia denotativa" opera um fechamento da estrutura semântica do texto, uma vez que é ela a responsável por estabelecer os parâmetros objetivos de leitura de um texto e salvaguardar o analista da ameaça da logomaquia. Pensando indutivamente na direção oposta, pode-se inferir que a conotação incide sobre a abertura de significações, o que é considerado por Greimas como modelos de interpretação dos "elementos estrangeiros". Nessa passagem, pode-se reconhecer um percurso que parte do uno ao múltiplo. No nível denotativo, os efeitos de sentido estariam estabilizados e objetivados, ao passo que o nível conotativo comportaria a multiplicidade de sentido desencadeada pela leitura, que nem sempre é unânime.

A homologia entre nível conotativo vs. nível denotativo e abertura $v s$. fechamento da significação é um ponto delicado. Conforme se vê no trecho comentado, Greimas aloca nas chamadas "isotopias denotativas" a estabilização das isotopias de leitura de um texto. Por exclusão, as "isotopias conotativas" ficariam então responsáveis pelos efeitos de sentido ulteriores. Essa associação pode ser melhor compreendida quando se tem em vista as correspondências entre essa oposição conceitual e aquela posta entre esquema e uso.

Ao discorrer sobre a hierarquia semiótica no pensamento de Hjelmslev, Sémir Badir observa que a análise denotativa ocupa-se das formas linguísticas ao passo que a análise conotativa detalha as particularidades do uso dessas formas (BADIR, 2004, p. 29). Algumas páginas depois, este autor nota que a análise conotativa permite dar conta da diversidade e das variabilidades semióticas presentes na experiência linguageira cotidiana. Seguindo essa disposição conceitual, as variantes sistematizáveis pela análise conotativa encontram-se no domínio do uso ao passo que as invariantes, detectáveis pela análise denotativa, pertencem ao esquema (BADIR, 2004, p. 57-62).

Até esse ponto, não se vê nenhuma discrepância com o raciocínio de Greimas, que pretendia enxergar na chamada "isotopia denotativa" um lugar de estabilização das estruturas da significação. No entanto, a associação dessa projeção hierárquica com o controle das leituras logomáquicas que assolam o texto parece ainda pouco clara, principalmente quando se tem em mente a oposição hjelmsleviana entre esquema e uso. 
Se assumíssemos essa linha de raciocínio a título de hipótese, então poderíamos concluir que o esquema opera um fechamento nos sentidos produzidos por um texto enquanto o uso opera uma abertura. Esse entendimento não reflete perfeitamente as conceituações acerca do uso que se firmaram no corpo teórico da semiótica. Em trecho de seu manual Caminhos da semiótica literária dedicado à práxis enunciativa e às relações entre estrutura $\mathrm{e}$ história, o semioticista Denis Bertrand sumariza as discussões acerca desse tema e chama atenção para a originalidade da inversão conceitual.

O resultado é na aparência paradoxal: com efeito, concebia-se intuitivamente o sistema como um conjunto fechado de regras e a fala como o exercício soberano de uma liberdade ('a liberdade da palavra'). A análise inverte as propostas, dando destaque, contrariamente, ao jogo das restrições que se impõem a toda enunciação, para além do simples dispositivo estabilizado das regularidades gramaticais. (BERTRAND, 2003, p. 87).

Longe de ser uma proposição inédita, a engenhosa inversão já estava presente nas reflexões de Greimas no estágio standard da teoria. Em texto intitulado "Estrutura e história" - publicado originalmente já em 1966 (mesmo ano da obra fundadora Semântica Estrutural) e republicado em $\mathrm{Du}$ sens - o autor declara que a história vem "fechar a porta a novas significações" disponíveis em virtualidade na estrutura semântica. Ao invés de agir como um "motor", a história seria o "freio" da produção de significações (GREIMAS, 1975a, p. 104). Na sequência, esse semioticista retoma explicitamente a oposição de Hjelmslev para ratificar essa ideia.

A partir da dicotomia hjelmsleviana, bem pouco explorada e que opõe a estrutura (= 'o esquema') ao 'uso', tornam-se possíveis novas extrapolações. Pode-se entender por uso, operacionalmente, a utilização que uma comunidade linguística faz da estrutura da significação de que dispõe, identificando-se então o conceito de uso com a historização da estrutura. Podemos nos utilizar, igualmente, do termo uso como o faz Hjelmslev, para designar a estrutura fechada pela história, de forma que, nesse caso, o problema das relações entre a estrutura e sua manifestação histórica parcial se vê situado num plano de reflexão homogênea. (GREIMAS, 1975a, p. 105, grifo do autor).

Uma rápida consulta ao verbete "Abertura" do Dicionário de Semiótica I dissipa definitivamente qualquer possibilidade de dúvida a esse respeito: “[...] pode-se dizer, assim, que o esquema de um universo semântico é aberto, enquanto seu uso corresponde a seu fechamento" (GREIMAS; COURTÉS, 2012, p. 17). O verbete "Fechamento" repete essa ideia de maneira quase idêntica: "Dir-se-á, então, que o esquema (ou estrutura) semântico desse universo é aberto, ao passo que seu uso (ou suas realizações na história) constitui, a todo momento, o fechamento dele" (GREIMAS; COURTÉS, 2012, p. 206). Quando se toma em consideração essas reflexões acerca da historicização das estruturas, torna-se mais difícil defender uma homologação estrita entre, de um lado, isotopia denotativa, estrutura e fechamento e, de outro lado, isotopias conotativas, uso e abertura. Para retomar o excerto de Greimas com o qual iniciamos estas reflexões, tudo indica que o autor estava mais preocupado naquele momento em estabelecer certos parâmetros para abordar sistematicamente o texto e alertar para os riscos de fazer uma interpretação precipitada dos estratos ideológicos. 
Sua preocupação em neutralizar a multiplicidade de leituras ideológicas geradas a partir de um único texto retorna em texto publicado em $D u$ sens $I I$ dedicado ao contrato de veridicção. Greimas procura abrigar dentro dos limites semióticos determinados problemas relacionados à dimensão sócio-histórica dos textos. As remissões a Hjelmslev mostram-se bem mais econômicas, como se o autor já desse por conhecidas as discussões sobre as linguagens de conotação travadas em momentos anteriores.

Essa resistência do texto a certas variações ideológicas contextuais e não a outras só se explica se se aceita que o texto possui suas próprias marcas de isotopias de leitura (e, no caso que nos preocupa aqui, suas marcas de veridiç̧ão) que limitam suas possibilidades. Em outros termos, a interpretação de Lotman deve ser integrada na teoria das linguagens de conotação hjelmslevianas e o semioticista, ao invés de evacuar o problema que o embaraça empurrando-o para o historiador, deve se esforçar para dar conta dele [o problema]. (GREIMAS, 1983, p. 106, grifo do autor, tradução nossa).

A mencionada interpretação de Lotman diz respeito à inscrição dos discursos individuais na esfera dos discursos sociais e às variações de avaliação dos textos em diferentes contextos de leitura. O exemplo citado por Greimas aponta que textos medievais tidos naquela época como religiosos passam a ser lidos alguns séculos depois como ficções literárias. É interessante notar que a expressão "isotopia denotativa” encontrada em Du sens é substituída em Du sens II por "isotopias de leitura". Em ambos os casos, elas representam o elemento estrutural responsável por estabilizar as produções de sentido que emanam do texto. Seguindo a argumentação de Greimas nesse mesmo texto, as linguagens de conotação poderiam por sua vez explicar as variações de leitura que despertaram o interesse de Lotman.

Nesse ponto, uma inversão da problemática vem dissipar o aparente paradoxo posto pelo jogo de abertura e fechamento de significações. Pode-se entender que, ao definir o núcleo invariante da significação de determinado texto, as ditas isotopias de leitura deixam em aberto os efeitos de sentido que podem ser extraídos a partir daquela estrutura básica. Confrontado com um dado texto, qualquer leitor deverá reconhecer a mesma estrutura invariante, construída em termos de transformações narrativas, arranjos modais, jogos de embreagem e debreagem etc., independentemente das diversas linhas de leitura e interpretação que cada leitor em particular pode projetar.

É nesse sentido que se pode afirmar que a estrutura promove uma abertura de significações. Para entender essa ideia, pode-se pensar na linha movediça que separa discursos religiosos e mitológicos em sua concepção mais corriqueira. Não obstante suas identidades em termos de configurações narrativas e discursivas, os segundos tendem a ser interpretados como invenções da imaginação enquanto os primeiros são lidos como portadores da verdade. Note-se que as isotopias denotativas, conforme entendidas por Greimas, não têm o poder de especificar tais linhas de interpretação.

As linguagens de conotação incidiriam exatamente nesse ponto, uma vez que elas permitem explicar por que determinados arranjos semióticos tendem a seguir certos protocolos tácitos de leitura mesmo não existindo nenhuma restrição de ordem estrutural. $\mathrm{O}$ grande interesse desse campo de investigações parece residir nos princípios de caráter sóciohistórico que regulam a circulação e recepção dos discursos. Por trás do véu de obviedade que envolve a troca dos discursos na vida cotidiana, esconde-se uma estrutura concessiva formulável nos seguintes termos: tais configurações discursivas assumem tendencialmente as mesmas linhas de leitura, embora não haja nenhuma obrigatoriedade a esse respeito. Aqui, 
reconhece-se claramente o fechamento operado pela dimensão sócio-histórica da prática discursiva sobre as possibilidades deixadas em aberto pela estrutura.

Essa discussão serve de forte contraevidência para a frequente crítica de que a semiótica da Escola de Paris ignorou a dimensão sócio-histórica do discurso (cf. FIORIN, 2011). Ao contrário, Greimas percebe argutamente o papel-chave da conotação no tratamento da historicidade dos textos. Além disso, é proveitoso observar que Greimas está tratando as chamadas isotopias de leitura enquanto marcas de veridicção. Essa tomada de posição pode ser confirmada por uma rápida consulta à quinta subseção do verbete "Isotopia" do Dicionário de Semiótica, em que o autor afirma expressamente que o jogo do ser e do parecer determina um plano isotópico (GREIMAS; COURTÉS, 2012, p. 277). A convocação das modalidades veridictórias não pode ser vista apenas como um expediente cômodo; ao contrário, ela mostra como as remissões mútuas entre conceitos contribuem para garantir a economia teórica da semiótica.

\section{Conotação e veridicção}

Não se pode ignorar o fato de que Greimas tenha resgatado as linguagens de conotação exatamente no capítulo de Du Sens II dedicado às questões da veridicção (GREIMAS, 1983, p. 103-113). Publicado pela primeira vez em 1980, o texto "Le contrat de véridiction" discute brevemente aspectos relacionados às distinções feitas na semiótica entre verossimilhança, veridicção e verdade. Já tendo definido em momento anterior os fundamentos dessas ideias, o texto trata do papel do verossímil e do fazer veridictório na construção de uma tipologia dos discursos dentro das culturas. À primeira vista, já se nota que o tratamento de Greimas dado às modalidades veridictórias ultrapassa aquele mecanismo modal que buscava explicar os jogos de enganos e revelações dos actantes no desenvolvimento do programa narrativo.

De certo modo, esse trabalho retoma as questões relacionadas ao ser e ao parecer dos objetos semióticos já levantadas em Du Sens. Logo no início de seu texto, Greimas observa que uma dada comunidade cultural admite a existência de discursos verossímeis, inverossímeis e discursos que não são nem verossímeis nem inverossímeis, como o científico e o filosófico. O autor destaca ainda a importância do fazer veridictório retomando a constatação obtida pelas pesquisas em psicologia segundo a qual crianças até determinada idade não são capazes de distinguir os personagens reais dos imaginários na televisão e comenta logo em seguida: "Um campo particular de pesquisas se desenvolve: trata-se de ver como se faz, a partir dessas confusões, a aquisição progressiva da 'realidade', isto é, da visão conforme o 'senso comum"' (GREIMAS, 1983, p. 103-104, tradução e grifo nosso).

É pouco provável que a noção de sens commun tenha sido retomada por mero acaso. A acepção empregada por Greimas nesse trecho breve e revelador vai ao encontro das ideias já trabalhadas em "Para uma sociologia do bom-senso"". Com uma argumentação sutil e surpreendente, o autor demonstra que o invólucro do "ambiente de realidade tranquilizadora" (1975a, p. 96) é um produto cultural de determinada sociedade e, portanto, deve ser adquirido pelo homem. Algumas linhas depois, Greimas reafirma a submissão desses efeitos de verdade às codificações culturais e relembra que, em diversas sociedades tribais africanas, as narrativas orais se dividem em "histórias verdadeiras" e "histórias para rir". O grande interesse dessa divisão é que, nestas culturas, o primeiro tipo de narrativa está associado aos

9 Cf. seção "Conotação e o 'sens commun"'. 
mitos e lendas e o segundo tipo, aos eventos cotidianos enquanto nas culturas europeias essa relação é inversa.

É no quadro dessas reflexões que se encaixa a declaração de Greimas acerca das marcas de veridicção e da reformulação das ideias de Y. Lotman em termos de linguagens de conotação, conforme discutido anteriormente. Em diversos momentos, as menções do semioticista francês à conotação vêm acompanhadas de referências à ideia, atribuída ao líder da semiótica russa, de postura adotada pelas culturas perante seus discursos. Na década de setenta, Greimas já entrevia tal possibilidade enquanto uma das ditas "zonas de conotação": "Deve-se distinguir um estudo das formas literárias ou poéticas, evidenciando sua forma específica e descrevendo seu estatuto estrutural particular, da atitude que uma sociedade adota face aos signos de sua linguagem" (GREIMAS, 1975a, p. 91, grifo nosso). Na década de oitenta, essa concepção é retomada em termos muito próximos.

Ora se, seguindo Hjelmslev, considera-se o signo como o resultado da semiose unindo os dois planos de expressão e de conteúdo e isto independentemente de suas dimensões sintagmáticas, vê-se que os discursos dos quais nos ocupamos são apenas signos complexos e que as 'atitudes' que as culturas adotam com relação a esses signos são suas interpretações metassemióticas conotativas. (GREIMAS, 1983, p. 107, tradução e grifo nosso).

A conotação enquanto acomodação das proposições de Lotman confere à definição de Hjelmslev um alcance teórico amplo. A dificuldade de operacionalizar essa leitura peculiar das linguagens de conotação se mostra no fato de que, ao longo da argumentação de Greimas, elas tenham passado para segundo plano em favor das reflexões acerca da construção do referente interno e da construção de regimes de veridicção no e pelo discurso.

Contudo, a atitude de Greimas não deve ser julgada precipitadamente como mera contradição. Em certo sentido, ela pode ser interpretada como um esforço em direção à economia teórica. Ao relacionar as atitudes da cultura frente aos signos com a questão do fazer persuasivo e interpretativo, Greimas encontra uma conexão entre a problemática já levantada em $\mathrm{Du}$ Sens e o fértil terreno das modalidades, mais especificamente o crer e o saber, conforme atesta o último parágrafo de "Le contrat de véridiction":

Propondo uma tal interpretação, todavia, nós apenas retornamos à problemática do crer na teoria da linguagem segundo a qual as epistemes, que recobrem as culturas, podem ser definidas e analisadas como linguagens de conotação. Mas, assim fazendo, nós exercemos, não nos esqueçamos, um fazer interpretativo, construtos de metalinguagem, um fazer que manifesta ostentatoriamente o saber sobre o crer. (GREIMAS, 1983, p. 113, grifo do autor, tradução nossa).

Nesse ponto, é preciso relembrar que o primeiro tomo do Dicionário de Semiótica já traz entradas referentes tanto às modalidades veridictórias e ao fazer interpretativo quanto à conotação e à metassemiótica. Ao sondar os verbetes "Crer", "Saber", "Epistêmicas, modalidades " e "Veridictórias, modalidades ", o semioticista não encontra nenhuma pista sobre a peculiar ligação entre conotação e veridicção revelada acima. Somente o verbete "Veridicção" evidencia esse elo. Após mencionar os mecanismos de produção de ilusão referencial e efeitos de verdade, Greimas explicita o parentesco entre a conotação e os regimes do fazer veridictório regulados pelos sujeitos da enunciação: 
Face a esse relativismo cultural que engendra diversos sistemas de conotações veridictórias, delineia-se uma reformulação da problemática da 'verdade': em decorrência de não ser mais considerado como a representação de uma verdade que lhe seria exterior, o discurso não pode mais contentar-se com a simples inscrição das marcas da veridicção. A verdade, para ser dita e assumida, tem de deslocar-se em direção às instâncias do enunciador e do enunciatário. (GREIMAS, COURTÉS, 2012, p. 531, grifo nosso).

Tomando por base o trecho acima, destaca-se a correlação da conotação com dois vetores conceituais fundamentais no corpo teórico da semiótica francesa: em primeiro lugar, a regulação dos regimes veridictórios e das condições de verdade internamente aos discursos e, em segundo lugar, o papel desempenhado pelos sujeitos da enunciação na assunção (ou eventualmente na suspensão) das "cláusulas" desse contrato veridictório. A relação estreita entre esses dois aspectos pode ser ratificada pelas investigações de Denis Bertrand (2006). Em artigo dedicado à posição-chave da metáfora da "tela do parecer" e da "mordida no real" em Du Sens, o autor comenta que a postura de Greimas visa reposicionar a questão da verdade na medida em que a desconecta dos critérios ontologizantes consagrados pela investigação lógica e a caracteriza como um produto resultante do fazer persuasivo e interpretativo dos sujeitos da enunciação. $\mathrm{O}$ autor destaca ainda que, sob esse ponto de vista, a fidúcia constitui o campo privilegiado sobre o qual se demarcam as balizas de confiança e desconfiança partilhadas pelos sujeitos no fazer veridictório (BERTRAND, 2006, p. 19).

No que concerne ao caráter discursivo da veridicção, o excerto manifesta nitidamente a recusa da semiótica greimasiana em tratar a "verdade" enquanto dado da realidade extralinguística. Nesse ponto, é curioso notar a retomada da conotação enquanto mediação cultural entre o homem e a semiótica do mundo natural. Embora dessa vez o ponto de ataque seja consideravelmente distinto das questões relacionadas à apreensão sensorial do sens commun, não é difícil reconhecer que ambas as discussões tratam igualmente do jogo semiótico entre o ser e o parecer. Ainda no que diz respeito aos regimes de veridicção, o verbete "Sociossemiótica" do Dicionário de semiótica I ratifica tanto as constatações registradas na entrada "Veridicção" e antecipa as reflexões de Du Sens II discutidas acima.

Um outro nível de conotação, bastante ligado ao primeiro, parece estar subjacente aos discursos e estabelecer o modo e o grau de veridicção que uma sociedade lhes atribui: aquilo que é 'realidade' e aquilo que não é senão 'ficção', aquilo que é uma 'história verdadeira' e aquilo que não é senão uma 'história para rir' (critérios para uma classificação dos gêneros literários e para uma tipologia dos 'mundos possíveis') dependem de uma ontologia cultural de ordem conotativa (GREIMAS; COURTÉS, 2012, p. 483, grifo nosso).

Graças aos conotadores, podemos distinguir textos críveis e não-críveis, autênticos e artificiosos, sinceros e fingidos. Por meio desse conceito, torna-se possível também trabalhar com mais rigor a ideia de efeitos de sentido. O grau de objetividade ou subjetividade do texto é avaliado de acordo com regras tácitas socialmente convencionadas que incidem sobre um conjunto heterogêneo de dados. Para os textos verbais, pode-se citar como exemplo a seleção do léxico, de estruturas sintáticas entre outros fenômenos comumente associados aos estudos do estilo. O reconhecimento dessas características ocorre sobremaneira por meio do 
sentimento de adequação dos falantes, o que reflete o caráter não-científico da conotação em Hjelmslev (cf. BADIR, 2004, p. 48).

O papel central de tal sentimento de adequação na avaliação dos valores conotativos não passou despercebido ao semioticista lituano. Em passagem da seção "Uma estética exaurida" de Da imperfeição (2002), o autor comenta as sutilezas veridictórias implicadas no corriqueiro hábito feminino de escolher roupas, que envolve elementos figurativos tão diversos e numerosos a ponto de inviabilizar a construção de um inventário paradigmático fechado e exaustivoVale a pena notar também que ao produto do enfeixamento dos inúmeros elementos figurativos são atribuídos valores conotativos (elegância, vulgaridade, etc.), cuja validade depende sobremaneira do fazer interpretativo do sujeito.

Mudando ligeiramente de assunto, consideremos a mulher que pratica a arte fútil de olhar vitrinas. (...) Com efeito, quando se trata de reconhecer um vestido 'muito simples' ou um tailleur 'chic', os elementos de informação submetidos ao julgamento são de ordem figurativa - linhas, cores, gestos, atitudes - mas requerem ser avaliados e dotados de significados de ordem conceitual: simplicidade, elegância, refinamento. $\mathrm{E}$ isso tanto mais quanto as figuras assim convocadas pertencem à dimensão prática da vestimenta e fazem parte das morfologias e dos programas funcionais: elas são extraídas de conjuntos demasiadamente diversos para serem arranjadas em inventários figurativos 'verticais' axiologicamente conotados. (GREIMAS, 2002, p. 77).

A trivialidade do exemplo dado camufla sua potência teórica. De fato, é possível reconhecer nessa pequena cena a verdadeira fertilidade do campo de atuação de uma sociossemiótica conforme delineada nos termos de Greimas. Raciocinando algo ingenuamente, não é difícil associar os processos de seleção e combinação que nutrem o mundo da moda ao entendimento discursivo de estilo. Assim sendo, pode-se compreender facilmente de que maneira qualificativos como "elegância", "extravagância", "comedimento" etc. configuram significados conotativos do sistema sociossemiótico descritíveis em termos de fisionomias estilísticas.

No que diz respeito à participação do enunciador e do enunciatário na regulação da verdade discursiva, pode-se encontrar uma correlação entre esta e a conotação nas ideias apresentadas na conferência "A enunciação: uma postura epistemológica", em que Greimas discute o papel fundamental da enunciação no conjunto de premissas epistemológicas que governam a pesquisa semiótica e declara explicitamente o vínculo orgânico entre pacto veridictório e enunciação: "Mais uma coisa: a enunciação é o lugar da veridicção" (GREIMAS, 1974, p. 9). Um pouco mais à frente, encontra-se novamente a questão da veridicção, dessa vez associada explicitamente à conotação.

Mas o que nos auxilia é saber que a enunciação pode ser enunciada num tipo de discurso. E é essa enunciação enunciada que podemos descrever sob forma de modelo e que dá modelos previsíveis para estudar as linguagens de conotação que nos signos são erráticas. O que quis evidenciar, para que isto não permaneça confuso, é um problema relativo à veridicção, que constitui o referente interno do discurso, por não termos referente externo, o contrato

10 A menção passageira ao tema da moda sugere resquícios deixados por trabalhos anteriores como La Mode en 1830. Essai de description du vocabulaire vestimentaire d'après les journaux de mode de l'époque (GREIMAS, 1948) e Système de la mode (BARTHES, 1967) no substrato intelectual do autor. A hipótese de um "retorno do recalcado" fica em aberto, aguardando dados bio-bibliográficos mais concretos. 
entre o destinador-narrador e o destinatário-leitor institui um referente interno de acordo com o grau de credibilidade do texto. (GREIMAS, 1974, p. 11, grifo nosso).

Embora os pontos de contato entre esses aspectos e a conotação estejam apenas sugeridos e suas implicações não sejam exploradas na sequência da explanação de Greimas, não seria razoável ignorar essa ligação. Sem correr o risco de extrapolar essas considerações, algumas conclusões podem ser ensaiadas. Assim como ocorre com a veridicção, a conotação está necessariamente atrelada à instância da enunciação, que pode ser reconhecida nas marcas deixadas no enunciado. É interessante notar que Greimas enxerga na chamada "enunciaçãoenunciada" uma maneira de domar as ocorrências erráticas da conotação. A fim de esclarecer certas imprecisões, Greimas faz glosa de sua própria assertiva e invoca o papel crucial dos sujeitos da enunciação no contrato veridictório. Essas considerações podem ser lidas como sementes das reflexões já discutidas neste trabalho e presentes no Dicionário I e em Du Sens II, obras que viriam a ser publicadas posteriormente.

Considerando a relação íntima entre veridicção e enunciação, Greimas enxerga na análise dos simulacros dos sujeitos da enunciação uma via de acesso para decifrar as regras tácitas que orientam a práxis comunicativa em determinado contexto social ou cultural. Alguns parágrafos antes nesse mesmo texto, o autor declara que as formas de interação reguladas socialmente se cristalizam no simulacro de enunciatário projetado no enunciado. Dito em outras palavras, o enunciador faz escolhas de acordo com a imagem que ele faz do enunciatário. Para retomar o exemplo dado por Greimas, o sujeito dá preferência a determinadas formas quando crê se dirigir a uma mulher, a um superior, a um estranho entre outros. Tais regras implícitas se apoiam sobre o pano de fundo de ordem cultural sobre o qual atuam os participantes da comunicação. Essa regulação da cultura sobre os discursos reflete justamente o entendimento de conotação adotado por Greimas enquanto "atitude das culturas face a seus signos". Se os membros de determinada comunidade não discordam de que se deve dirigir diferentemente a um idoso, a uma mulher ou a uma criança, é porque há um código de ordem cultural subjacente que organiza a interação social.

Certamente, há coisas mais complicadas, tudo é um jogo da veridicção, que constitui o referente social, que constitui, no fundo, uma sintaxe conotativa da linguagem humana, da comunicação humana. O importante não é tanto o que as pessoas dizem, mas o que eu acho que as pessoas dizem. [...] Há portanto um jogo psíquico e sociossemiótico complexo que deriva do que Hjelmslev chama de linguagem de conotação. De alguma forma, há uma passagem que se pode trabalhar ao tratarmos da enunciação, entre o que está presente no texto como simulacros de comunicação social e o que é a comunicação social em si mesma. (GREIMAS, 1974, p. 10).

No trecho acima, observa-se com nitidez a relação entre conotação, veridicção e o papel dos sujeitos da enunciação na construção dos jogos complexos que se instalam entre esses três vértices. As confluências entre esses conceitos sugerem certa consistência no tratamento de questões que podem parecer distantes a princípio. Se o enunciador consegue dar a seu texto um ar de seriedade (fazer-parecer-verdadeiro) ou de comicidade (fazer-parecerfalso), é porque ele está consciente dos protocolos culturais implícitos que regulam a práxis discursiva. Não é demasiado relembrar que a eficácia dessa construção depende da validação dada pelo fazer-interpretativo do enunciatário. Quando este último reconhece as marcas de veridicção espalhadas pelo texto e aceita o contrato proposto pelo enunciador, então pode-se 
afirmar que ambos estão de acordo sobre as linhas de força que orientam o contrato veridictório.

Os efeitos de sentido resultantes do "jogo psíquico e sociossemiótico" de simulacros entre enunciador e enunciatário são tratados explicitamente como fenômenos conotativos por Greimas em seu Semiótica e ciências sociais (1981), mais especificamente na seção "Modelos teóricos em sociolinguística". Embora o tema esteja mais relacionado ao âmbito da estilística, gostaríamos de destacar a seguinte passagem, que comprova a conexão orgânica entre veridicção, conotação e o jogo de simulacros da práxis da comunicação humana.

Assim, supondo-se que o locutor L1 conote seu discurso como um discurso de mulher, o locutor L2 procurará reconverter seu discurso em um discurso dirigido a uma mulher. (...) Um último exemplo, enfim, seria o aparecimento no adulto de uma espécie de falsa linguagem infantil, um baby speech que é uma adaptação ao locutor-criança e que frequentemente provoca neste um sentimento de superioridade e de condescendência. (GREIMAS, 1981, p. $62)$.

Por mais evidente que possa parecer, não pouparemos a observação de que essas readaptações de discurso decorrem diretamente dos papéis sociais desempenhados pela mulher e pela criança. Sob esse ponto de vista, observa-se com nitidez o laço estreito que liga a conotação à dimensão social das práticas discursivas. Assim sendo, pode-se prever que há uma boa dose de convencionalização e cristalização do uso dos conotadores. Seguindo essa linha de raciocínio, chega-se ao entendimento de conotação mais propagado, nomeadamente aquele que a define como construção de estilos e de fisionomias individuais e coletivas.

\section{Para concluir}

Ao longo desse breve percurso, foram discutidas algumas facetas do conceito de conotação conforme formulado por Louis Hjelmslev e tratado por A. J. Greimas. Em diversos momentos do texto, fez-se referência ao entendimento de conotação enquanto axiologização de fenômenos de estilo cujos desdobramentos não foram abordados aqui. Também não foram tratadas questões relacionadas à hierarquização da análise, que marcam as diferenças entre a concepção hjelmsleviana (em grande medida também presente na leitura de Greimas) das diversas acepções da conotação que circulam nos estudos da linguagem em geral. A apresentação e discussão dos dados obtidos nessa frente de investigação aguardam publicação em momento oportuno.

Mais do que apenas listar ocorrências lexicais - para o que seria mais eficiente uma metodologia baseada no tratamento eletrônico de corpus - a abordagem elegida privilegiou a discussão e a interpretação crítica do material. A estratégia adotada buscou traçar o lugar de pertinência da conotação na intrincada rede de conceitos da semiótica. A proximidade com questões relacionadas ao ser e ao parecer é o ponto de articulação que associa a conotação tanto ao jogo de isotopias quanto ao sens commun. Tanto em um como em outro caso, o conceito de conotação cumpre o papel de elemento mediador capaz de contribuir para o diálogo da semiótica com outros domínios.

No primeiro cenário, a conotação pode agir como elemento mediador do aparato teórico da semiótica greimasiana com as questões trabalhadas pela semiótica lotmaniana. No segundo cenário, as relações entre conotação e sens commun constituem um novo ingrediente a ser acrescentado nas discussões sobre o estatuto epistemológico da percepção em semiótica. Aqui, a fenomenologia aparece como domínio privilegiado de interlocução, sobretudo quando 
se toma em consideração as questões relacionadas à "cortina de fumaça" e à "mordida sobre o real".

Em ambas as rotas de investigação, fica nítido que a conotação não pode ser reduzida - para retomar as palavras do próprio Greimas em Du sens - à "reintrodução de uma pseudoestilística ultrapassada". Ao invés disso, em consonância com o semioticista lituano, consideramos que é preferível enxergar aí o estabelecimento de uma nova dimensão na economia teórica da disciplina. O conceito de conotação permite extrair todas as consequências da análise em níveis hierarquizados, pois possibilita dar tratamento formal a dados que são tidos como substanciais até determinado patamar de investigação. Sob nosso ponto de vista, esse refinamento heurístico representa uma grande vantagem da semiótica francesa sobre outras abordagens que tratam indistintamente fenômenos de ordens distintas. Portanto, não se trata simplesmente de resgatar um metatermo e colocá-lo em circulação, mas sim reavaliar o lugar desse conceito na arquitetura geral da teoria.

\section{REFERÊNCIAS}

ABBAGNANO, N. Dicionário de filosofia. Tradução da $1^{a}$ edição brasileira coordenada e revista por Alfredo Bosi; revisão da tradução e tradução dos novos textos por Ivone Castilho Benedetti, 4. ed. São Paulo: Martins Fontes, 2000.

ARENDT, H. La condition de l'homme moderne. Paris: Calman-Lévy, 1983. "La crise de la culture". In : . La crise de la culture. Huit exercises de pensée politiques. Paris: Gallimard (Idées), 1972.

ARRIVÉ, M. "Estruturação e destruição do signo em alguns textos de Jarry". In: GREIMAS, A. J. Ensaios de semiótica poética. São Paulo: Cultrix/Editora da Universidade de São Paulo, 1975, p. 79-95.

BADIR, S. Hjelmslev. Paris: Les belles lettres, 2004.

BARTHES, R. Système de la mode. Paris, Édition du Seuil, 1967.

Elementos de semiologia. 17. ed., São Paulo: Cultrix, 2004 [1964].

BEIVIDAS, W.; LOPES, I. C. "Interdisciplinaridade: Triagem e mistura na identidade da semiótica”. In: PORTELA, J. C. [et al.] (Org.). Semiótica: identidade e diálogos. São Paulo: Cultura Acadêmica, 2012, p. 33-47.

BERTRAND, D. Caminhos da semiótica literária. Bauru: EDUSC, 2003.

. 'Le sens dans 'Du sens': entre 'écran de fumée' et 'morsure sur le réel' ". Protée, vol. 34, n. 1, 2006. p. 10-22.

"Structure et sensibilité". Nouveaux Actes Sémiotiques. NAS, 2009, n. 112.

Disponível em: 〈http://epublications.unilim.fr/revues/as/2880>. Acesso em: 02 nov. 2012.

BLACKBURN, S. Dicionário Oxford de filosofia. Tradução de Desidério Murcho et. al. Rio de Janeiro: Jorge Zahar, 1997.

BLOOMFIELD, L. Le langage. Paris, Payot, 1970.

BUNGE, M. Dicionário de filosofia. Tradução de Gita K. Guinsburg. São Paulo: Perspectiva, 2002.

CAYGILL, H. Dicionário Kant. Tradução de Álvaro Cabral. Rio de Janeiro: Jorge Zahar, 2000.

CAÑIZAL, E. P. “A intertextualidade conotada”. In: Significação, n. 8, São Paulo, out./1990, p. 63-74.

DOSSE, F. História do estruturalismo: o campo do signo. v. 1. São Paulo: Ensaio, 1993.

FAGES, J. B. Comprendre Roland Barthes. Toulouse: Privat, 1979. 
FIORIN, J. L. "Semiótica e história". Cadernos de Letras da UFF - Dossiê: Linguagens em diálogo n. 42, p. 15-34, 2011.

GREIMAS, A. J. La Mode en 1830. Essai de description du vocabulaire vestimentaire d'après les journaux de mode de l'époque. Tese (Doutorado em Letras). Paris: datilografado, 1948. $431 \mathrm{f}$.

. "A enunciação: uma postura epistemológica". Significação - Revista Brasileira de Semiótica, n. 1, Centro de Estudos Semióticos A. J. Greimas: Ribeirão Preto, 1974. p. 09-25

. Sobre o sentido: ensaios semióticos. Petrópolis: Vozes, 1975a [1970].

Paulo, $1975 b$.

Ensaios de semiótica poética. São Paulo: Cultrix/Editora da Universidade de São

. Semântica estrutural. 2. ed. São Paulo: Cultrix, 1976a [1966].

Semiótica e ciências sociais. São Paulo: Cultrix, 1981.

Du Sens II: essais sémiotiques. Paris: Seuil, 1983.

“Conversation”. Versus, n. 43, Milão, 1986. p. 41-57.

Da imperfeição. São Paulo: Hacker Editores, 2002 [1987].

GREIMAS, A. J.; COURTES, J. Sémiotique: dictionnaire raisonné de la theorie du langage. v. 2. Paris: Hachette, 1986.

Dicionário de semiótica. São Paulo: Contexto, 2012.

GREIMAS, A. J.; FONTANILLE, J. Semiótica das paixões. São Paulo: Ática, 1993.

GREIMAS, A. J.; LANDOWSKI, E. Análise do discurso em ciências sociais. São Paulo: Global, 1986 [1979].

HÉNAULT, A. História concisa da semiótica. São Paulo: Parábola Editorial, 2006.

HJELMSLEV, L. Prolegômenos a uma teoria da linguagem. São Paulo: Perspectiva, 2006.

KRISTEVA, J. "Semanálise e produção de sentido. Alguns problemas de semiótica literária a propósito de um texto de Mallarmé". In: GREIMAS, A. J. Ensaios de semiótica poética. São Paulo: Cultrix/Editora da Universidade de São Paulo, 1975, p. 238-268.

LALANDE, A. Vocabulário técnico e crítico da filosofia. 3. ed. São Paulo: Martins Fontes, 1999.

LOPES, E. A identidade e a diferença: raízes históricas das teorias estruturais da narrativa. São Paulo: Editora da Universidade de São Paulo, 1997.

LORIES, D. Le sens commun et le jugement du Phronimos: Aristote et les Stoïciens. Louvain-La-Neuve: Peeters, 1998.

PARRET, H. "Common Sens and Basic Beliefs: from Certainty to Happiness". In:

(Org.) On believing: epistemological and semiotic approaches. [De la croyance: approches épistémologiques et sémiotiques]. Berlin, New York: Walter de Gruyter, 1983.

PELLEGRIN, P. Dictionnaire Aristote. Paris: Ellipses, 2007.

SONESSON, G. "Denotation/Connotation". s/d. Disponível em: <http://glossematics.org/forum/semisetp.htm>. Acesso em : 15 jan. 2013.

ZARADER, J. P. Dictionnaire de philosophie. Paris: Ellipses, 2007.

ZILBERBERG, C. "A propos de l'édition française des 'Nouveaux essais' de Louis Hjelmslev". Versus, n. 43, p. 129-140, gennaio-aprile, 1986.

"Síntese de gramática tensiva". Significação - Revista Brasileira de Semiótica, n.

25. São Paulo, Annablume, 2006.

Editorial, 2011.

Elementos de semiótica tensiva. São Paulo: Ateliê

Recebido em: 15/09/13

Aprovado em: 18/11/13 